\title{
Prolonged Deprivation Profiles of three Groups: A study in a Border Village of Cooch Behar, West Bengal
}

\author{
Sudipta Kumar Behera ${ }^{1 *}$, Ratna Dhar ${ }^{2}$, Dipak K. Adak ${ }^{1}$
}

\section{ABSTRACT}

Level of deprivation was examined in three individual groups in a border village namely, Kalmati in Dinhata Block-II, District Cooch Behar, West Bengal, which is situated in IndoBangladesh border. The village has three distinct geographical features - Group- 1) hamlets inside village kalmati, Group- 2) hamlets ahead of fence in Kalmati but situated before Bangladesh border and Group- 3) hamlets situated in erstwhile Bangladesh Chhitmahalsin side Kalmati. The sample consists of 346 subjects. Out of which, 123 samples belong to Group-1, 103 belong to Group-2 and rest i.e. 120 samples belong to Group- 3. The individuals fail to organise from adequate resources of physical, social, mental and emotional support from their immediate environment and society at large. Prolonged deprivation from the said facilities affects adversely physical growth as well as mental health of three individual groups. This was measured by Prolonged Deprivation Scale (PDS). The 15 areas of deprivation of PDS were analysed. The profiles differ significantly in some of the cases. Though the percentage of higher level of deprivation is similar in three groups, percentages of lower levels of deprivation differ among each other.

Keywords: Deprivation Areas, Indo-Bangladesh Border, West Bengal.

Deprivation denotes to certain deficiencies in the environment which are not only there but also felt as such by the individuals. It relates to certain features of the environment that are absent or inadequate in certain degree which cause an impact on the functioning of the individuals. Social scientists are greatly concerned about the impact of socio-cultural and economic deprivation on the overall development of the individual. Evidently, poverty is one of the components of deprivation. The essence of poverty is inequality. The poor are deprived in comparison with the rich and affluent. Limited opportunities are provided for their growth and development. This makes them dissatisfied and frustrated.

"Deprivation" is the word derived from the verb "to deprive" which means to dispossess (a person or an object) and it implies a "felt loss". Nurcombe (1970) has stated that deprivation refers strictly to a dispossession or loss of privileges, opportunities, material goods and the like.

\footnotetext{
${ }^{1}$ Anthropological Survey of India, 27 Jawaharlal Nehru Road, Kolkata, India

${ }^{2}$ Anthropological Survey of India, CGO Complex, Seminary Hills, Nagpur, India *Corresponding Author

(c) 2015 I S Behera, R Dhar; licensee IJIP. This is an Open Access Research distributed under the terms of the Creative Commons Attribution License (http://creativecommons.org/licenses/by/2.0), which permits unrestricted use, distribution, and reproduction in any Medium, provided the original work is properly cited.
} 


\section{Prolonged Deprivation Profiles of three Groups: A study in a Border Village of Cooch Behar, West Bengal}

This may occur with reference to three inter-related sets of basic needs i.e., physical, psychological and social cultural. The concept of deprivation has been used frequently as an explanatory construct as well as empirical variable to account for a variety of behavioural characteristics observed under natural as well as laboratory setting (Mishra and Tripathi 1980). In laboratory animal, psychologists in their experiments have extensively used setting deprivation as a source of motivation. Deprivation of food, water and sex, etc., is used to motivate the animal of subsequent learning. In studies done in natural settings deprivation has come to acquire a variety of connotations. It is used interchangeably with other terms such as cultural deprivation (Riesseman 1962; Wight et al. 1970), social and cultural disadvantaged (Havighurst 1962), psychological deprivation (Langmeier 1972) and social deprivation (Tulkin 1972).

In India, a considerable section of the population fail to organise from adequate resources of physical, social, mental and emotional support from their immediate environment and society at large. Prolonged deprivation from said facilities affects adversely physical growth as well as mental health of young individuals. The evidence of wider gaps in income inequality between different family types, different economic status groups, different regions have been found in several studies (Walker and Walker, 1981; Berclay, 1995; Hills, 1995; Goodman et.al., 1997; Hills 1998a). Scientific study of prolonged deprivation of individuals assume special significance in the contemporary world as the prolonged deprivation ascribed for individuals are of the important conditions for socioeconomic development of the country. In this backdrop the extent of deprivation of three individual groups i.e. individuals of Kalmati village (inside the Indian fence), individuals of Kalmati village (ahead the fence i.e. in Bangladesh side) and individuals of erstwhile Chhitmahals inside the Kalmati village seems to be meaningful for study in this respect.

\section{MATERIALS AND METHODS}

Present study was conducted in village Kalmati, which is an international border village of IndoBangladesh Border. Kalmati is situated in Dinhata II Block of Cooch Behar district, West Bengal. For the sake of study three groups were made- Group-1:individuals from Kalmati village (inside the Indian fence), Group-2: individuals from Kalmati village (ahead the fence i.e. in Bangladesh border side) and Group-3: individuals from erstwhile Bangladesh Chhitmahals inside the Kalmati village. 


\section{Prolonged Deprivation Profiles of three Groups: A study in a Border Village of Cooch Behar, West Bengal}

Sample: A total of 346 subjects were examined. Break-up of which is as follows:

\begin{tabular}{|l|l|l|l|}
\hline Individuals & Male & Female & Total \\
\hline Group-1 & 101 & 22 & 123 \\
\hline Group-2 & 83 & 20 & 103 \\
\hline Group-3 & 102 & 18 & 120 \\
\hline
\end{tabular}

Prolonged Deprivation Scale (PDS) developed by Misra and Tripathi (1977) provides information regarding fifteen areas of physical, social and emotional deprivation levels of the respondents. A 15 point profile of deprivation is computed for each group. Technique of profile analysis has been implemented to examine the differences between patterns to profiles of deprivation of three individual groups of Kalmati village- inside the fence, ahead the fence and Bangladesh Chhitmahals.

The Bengali Version of PDS was used to measure the level of prolonged deprivation of three groups of individuals of Kalmati village. The inventory consists of 96 statements with Likert type responses with five alternative responses. The scale measures 15 areas of life situation and experimental domain where deprivation could occur. The areas of deprivation include- 1) Housing conditions, 2) Home environment, 3) Economic sufficiency, 4) Food, 5) Clothing, 6) Formal education experience, 7) Childhood experience, 8) Rearing experience, 9) Characteristics of parents, 10) Interaction with parents, 11) Motivational experience 12) Emotional experience, 13) Travel and recreation, 14) Religious experience and 15) Socio-culture experience. The five alternative answers were assigned with score values of 1,2,3,4 and 5 respectively except the items, 70, 74, 75 and 77. For these items the score values were assigned inversely for the responses A B C Dand E. Total score was obtained by adding the scores of all 96 items. Higher score indicates higher level of deprivation and vice versa. On the basis of the obtained score by the subjects, individuals with a very high score with a value above 75th percentile was considered as highly deprived, while low scores with a value below 25th percentile was considered as individuals with low degree of deprivation. According to Misra and Tripathi (1977) the fifteen areas of life situation and experimental domain are as follows: 
Prolonged Deprivation Profiles of three Groups: A study in a Border Village of Cooch Behar, West Bengal

\begin{tabular}{|c|c|c|c|}
\hline $\begin{array}{l}\text { Sl. } \\
\text { No. }\end{array}$ & $\begin{array}{l}\text { Depri } \\
\text { Area }\end{array}$ & Items & Coverage of various items of PDS \\
\hline 1 & $\begin{array}{l}\text { Housing } \\
\text { condition }\end{array}$ & $1-6=6$ & $\begin{array}{l}\text { Coverage the type \& sufficiency of residential } \\
\text { accommodation and its physical status, facilities available } \\
\text { in it, spatial location and neighbourhood. }\end{array}$ \\
\hline 2 & $\begin{array}{l}\text { me } \\
\text { ironment }\end{array}$ & $7-14=8$ & $\begin{array}{l}\text { Concerned with household gadgets and equipment } \\
\text { including pots and pans, cooking utensils, furniture, water } \\
\text { facility, lighting arrangement, agricultural and other } \\
\text { occupational implements available in home, transport } \\
\text { facilities, printed literature available in home, and other } \\
\text { utilitarian mechanical gadgets. }\end{array}$ \\
\hline 3 & ic & $21=7$ & $\begin{array}{l}\text { Deals with economic condition, sources of income, total } \\
\text { area and type of agricultural land, cattle possessed, } \\
\text { orchard, condition of debt, and level of economic } \\
\text { difficulties. }\end{array}$ \\
\hline 4 & Food & $-25=4$ & $\begin{array}{l}\text { ne the eating habit, types of meals indicating their } \\
\text { value as well as physical \& mental health. }\end{array}$ \\
\hline 5 & g & $=4$ & $\begin{array}{l}\text { ed with type of clothing used, sufficiency of } \\
\text { lse of bed and foot wears etc. }\end{array}$ \\
\hline 6 & $\begin{array}{l}\mathrm{E} \\
\mathrm{e}\end{array}$ & $=7$ & $\begin{array}{l}\text { Dealing with age of school entrance, educational } \\
\text { attainment, years of schooling, attendance in school, } \\
\text { relations with teachers, interest in extra-curricular activities } \\
\text { and interaction with peer group. }\end{array}$ \\
\hline 7 & e & $1=5$ & $\begin{array}{l}\text { Pertaining to parental care during early years of life, } \\
\text { attention and affection received from parents and parental } \\
\text { discipline. }\end{array}$ \\
\hline 8 & 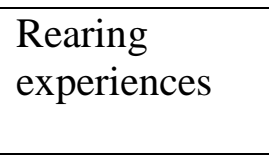 & $-48=7$ & $\begin{array}{l}\text { Interactional experiences of various sorts. Opportunity of } \\
\text { interaction with friends, experience of visiting market and } \\
\text { other places, participation in household activities etc. }\end{array}$ \\
\hline 9 & 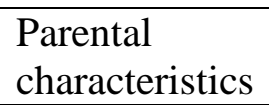 & $5=7$ & $\begin{array}{l}\text { Referred to parents' educational status, income, social } \\
\text { prestige, physical and mental health, etc. }\end{array}$ \\
\hline 10 & $\begin{array}{l}\text { Interaction } \\
\text { with parents }\end{array}$ & $=6$ & $\begin{array}{l}\text { Included expression of feelings before parents, adjustment } \\
\text { problems and expectations, etc. }\end{array}$ \\
\hline 11 & $\begin{array}{l}\text { Motivational } \\
\text { experiences }\end{array}$ & $62-72=11$ & $\begin{array}{l}\text { Satisfaction of psychological needs, such as, affiliation, } \\
\text { curiosity, decision-making, power, initiative and interest } \\
\text { etc. }\end{array}$ \\
\hline 12 & $\begin{array}{l}\mathrm{E} \\
\mathrm{e}\end{array}$ & $80=8$ & $\begin{array}{l}\text { Deals with pleasure, fear, avoidance, sympathy, anxiety, } \\
\text { praise, and reward, etc. }\end{array}$ \\
\hline 13 & $\begin{array}{l}\text { Travel and } \\
\text { recreation }\end{array}$ & $84=4$ & $\begin{array}{l}\text { Pertaining to sources of recreation, variety of recreational } \\
\text { experiences, leisure time and experiences to travel. }\end{array}$ \\
\hline 14 & Religious & $85-87=3$ & $\begin{array}{l}\text { Items on God worship, life rituals and knowledge of other } \\
\text { religions were included. }\end{array}$ \\
\hline 15 & $\begin{array}{l}\text { Socio-cultural } \\
\text { experiences }\end{array}$ & $88-96=9$ & $\begin{array}{l}\text { Deals with social interactions with respect to acceptance of } \\
\text { food, water, participation in social activities, social prestige } \\
\text { of person and contact with city. }\end{array}$ \\
\hline
\end{tabular}




\section{Prolonged Deprivation Profiles of three Groups: A study in a Border Village of Cooch Behar, West Bengal}

\section{RESULTS AND DISCUSSION}

Average scores of PDS of three individual groups are furnished in Table 1 for 15 areas of deprivation. In the present study higher PDS is indicative of higher level of deprivation. Lowest mean score of deprivation is recorded in childhood experiences, whereas highest mean score is in motivational experiences, which is true for all the three groups.

Mean scores of deprivation areas ranges between 11.18 in childhood experiences and 37.12 in motivational experiences in group 1. Low level of mean scores is recorded in the areas of religious experiences (11.2), travel and recreation (14.42), clothing (14.97), food (16.26) and interaction with parents (16.34). On the other hand, high levels of mean scores are recorded in the areas of parental characters (24.67), socio-cultural experiences (25.01), emotional experiences (25.90), economic sufficiency (28.67) and home environment (29.28). The other areas of deprivation show intermediate scores (Table 1).

In group 2 mean scores of deprivation areas ranges between 9.89 in childhood experiences and 35.65 in motivational experiences. Variables of deprivation areas like religious experiences (11.07), travel and recreation (13.95), clothing (14.41) and food (15.89) are characterized with low level of mean scores in this group. Side by side, in the areas like parental characteristics (22.97), socio-cultural experiences (23.37), housing condition (23.41), emotional experiences (24.98) show high level of mean scores. Other areas of deprivation in this group fall in between high and low level of mean scores (Table 1).

Average scores of PDS ranges between 8.53 in childhood experiences and 35.2 in motivational experiences in group 3. Low mean scores are recorded in the areas of religious experiences (10.17), travel and recreation (14.07), clothing (15.31) and interaction with parents (15.94). While, in parental characteristics (25.09), emotional experiences (26.83), economic sufficiency (28.68) and home environment (31.81)high mean scores are recorded (Table 1). For a clear view of the situation these results are shown in Figure 1. 
Prolonged Deprivation Profiles of three Groups: A study in a Border Village of Cooch Behar, West Bengal

Table 1: Means of 15 variables (areas of deprivation) of three individual groups

\begin{tabular}{|l|l|l|l|l|}
\hline Sl. No. & $\begin{array}{l}\text { Deprivation area } \\
\text { (variables) }\end{array}$ & $\begin{array}{l}\text { Group-1 } \\
\text { (individual } \\
\text { inside } \\
\text { fence-India } \\
\text { side) }\end{array}$ & $\begin{array}{l}\text { Group-2 } \\
\text { (individual } \\
\text { thead the fence- } \\
\text { Bangladesh } \\
\text { side) }\end{array}$ & $\begin{array}{l}\text { Group- } \\
\text { 3(individuals from } \\
\text { erstwhile } \\
\text { Bangladesh } \\
\text { Chhitmahals- } \\
\text { inside the Kalmati } \\
\text { village) }\end{array}$ \\
\hline 1 & Housing condition & 23.02 & 23.41 & 23.13 \\
\hline 2 & Home environment & 29.28 & 28.01 & 31.81 \\
\hline 3 & Economic sufficiency & 28.67 & 27.25 & 28.68 \\
\hline 4 & Food & 16.26 & 15.89 & 16.71 \\
\hline 5 & Clothing & 14.97 & 14.41 & 15.31 \\
\hline 6 & Educational experiences & 20.78 & 20.53 & 24.16 \\
\hline 7 & Childhood experiences & 11.18 & 9.89 & 8.53 \\
\hline 8 & Rearing experiences & 22.85 & 22.70 & 21.82 \\
\hline 9 & Parental characteristics & 24.67 & 22.97 & 25.09 \\
\hline 10 & Interaction with parents & 16.34 & 16.14 & 15.94 \\
\hline 11 & Motivational experiences & 37.12 & 35.65 & 35.20 \\
\hline 12 & Emotional experiences & 25.90 & 24.98 & 26.83 \\
\hline 13 & Travel and recreation & 14.42 & 13.95 & 14.07 \\
\hline 14 & Religious experiences & 11.20 & 11.07 & 10.17 \\
\hline 15 & Socio-cultural & 25.01 & 23.37 & 22.43 \\
\hline & experiences & & & \\
\hline
\end{tabular}


Prolonged Deprivation Profiles of three Groups: A study in a Border Village of Cooch Behar, West Bengal

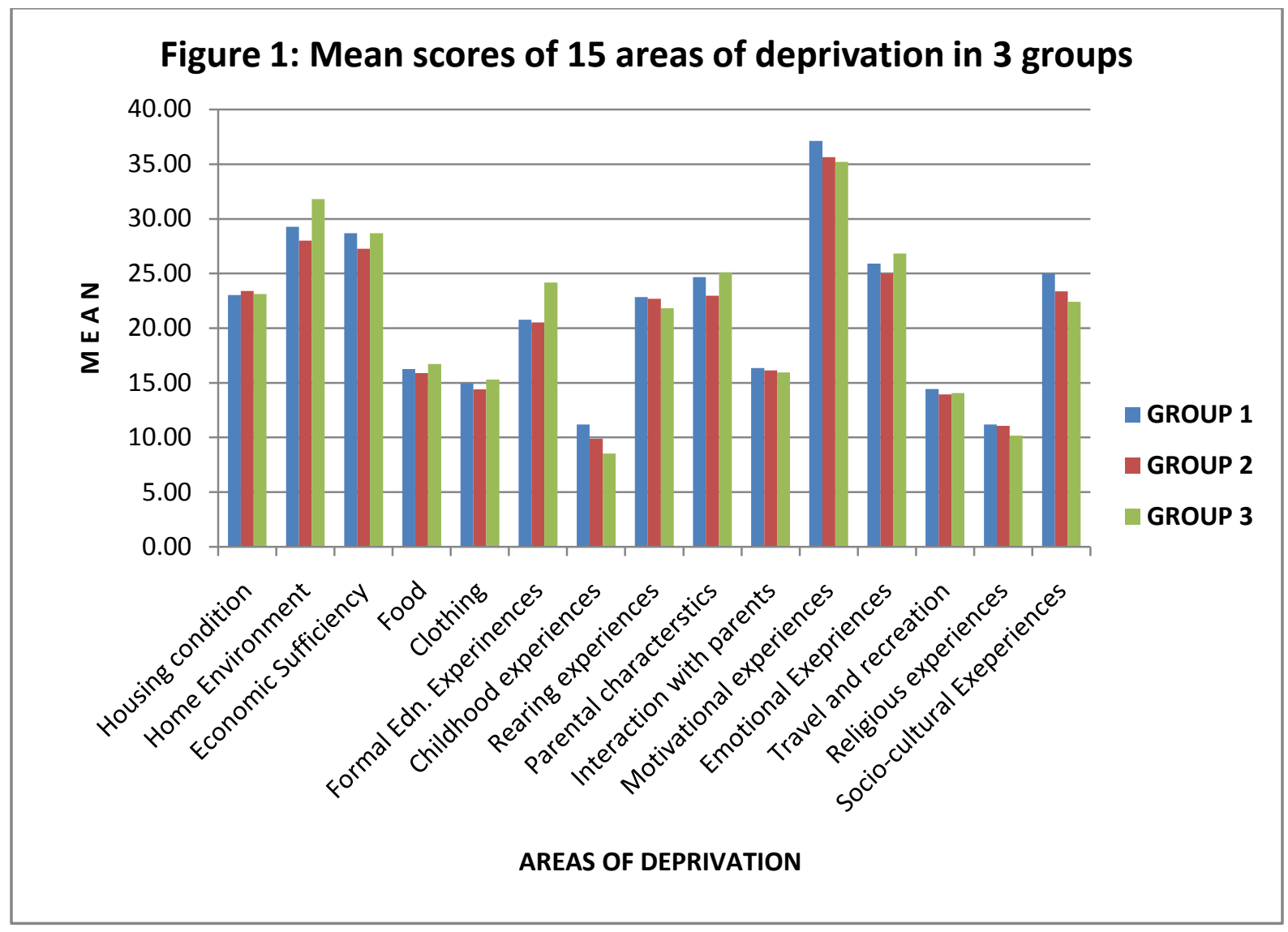

Table 2: Area-wise comparison of two groups (t-values)

\begin{tabular}{|l|l|l|l|l|}
\hline $\begin{array}{l}\text { Sl. } \\
\text { No. }\end{array}$ & $\begin{array}{l}\text { Deprivation area } \\
\text { (variables) }\end{array}$ & $\begin{array}{l}\boldsymbol{t} \text { value: group } \mathbf{1} \\
\text { vs 2 }(\mathbf{d f}=\mathbf{2 2 4})\end{array}$ & $\begin{array}{l}\boldsymbol{t} \text { value: group } \mathbf{2} \\
\text { vs3 }(\mathbf{d f}=\mathbf{2 2 1})\end{array}$ & $\begin{array}{l}\boldsymbol{t} \text { value: group } \\
\mathbf{1 v s 3}(\mathbf{d f}=\mathbf{2 4 1})\end{array}$ \\
\hline 1 & Housing condition & 0.67 & 0.49 & 0.32 \\
\hline 2 & Home environment & 1.60 & $5.46^{*}$ & $4.51^{*}$ \\
\hline 3 & Economic sufficiency & 1.95 & $2.01^{*}$ & 0.02 \\
\hline 4 & Food & 0.68 & 1.60 & 1.55 \\
\hline 5 & Clothing & 1.00 & 1.70 & 0.90 \\
\hline 6 & Educational experiences & 0.27 & $4.02^{*}$ & $4.60^{*}$ \\
\hline 7 & Childhood experiences & 1.83 & 2.11 & $5.33^{*}$ \\
\hline 8 & Rearing experiences & 0.17 & 1.05 & $2.04^{*}$ \\
\hline 9 & Parental characteristics & $2.46^{*}$ & $3.31^{*}$ & 0.90 \\
\hline 10 & Interaction with parents & 0.24 & 0.24 & 0.65 \\
\hline 11 & Motivational experiences & 1.44 & 0.44 & $2.25^{*}$ \\
\hline 12 & Emotional experiences & 1.23 & 0.17 & 0.08 \\
\hline 13 & Travel and recreation & 0.78 & 0.18 & 0.86 \\
\hline 14 & Religious experiences & 0.23 & 1.49 & $2.89^{*}$ \\
\hline 15 & Socio-cultural experiences & 1.65 & 1.04 & $3.09^{*}$ \\
\hline
\end{tabular}




\section{Prolonged Deprivation Profiles of three Groups: A study in a Border Village of Cooch Behar, West Bengal}

Taking into consideration all these deprivation areas (variables) it is found from Table 2 that individuals of group 1 differ from group 2 in 1 out of 15 variables, whereas between group 2 and 3 significant differences have been noticed in 4 out of 15 variables. On the other hand group 1 differs significantly from group 3 in 7 out of 15 variables. Thus it appears that individuals of groups 1 and 3 express prolonged deprivation in higher level than that of the individuals of group 2.

It can be mentioned in this context that though the individuals of group 2 are deprived of many basic amenities like electricity, health and educational infrastructure than their counterpart (group 1) they possess considerably higher agricultural land and their economic condition is better than the individuals of group 1. As a result PDS is recorded to be considerably lower in group 2 in all the deprivation areas excepting the area namely housing condition than group 1. On the other hand individuals of group 3 also show higher PDS in many areas like group 1. Values of t-test corroborate with these findings.

Table 3: Degree of deprivation in three groups

\begin{tabular}{|l|l|l|l|l|l|l|}
\hline \multirow{2}{*}{ Percentile } & \multicolumn{2}{l|}{ Group-1 (N=123) } & \multicolumn{2}{l|}{ Group-2 (N=103) } & \multicolumn{2}{l|}{ Group-3 (N=120) } \\
\cline { 2 - 7 } & $\mathrm{N}$ & $\%$ & $\mathrm{~N}$ & $\%$ & $\mathrm{~N}$ & $\%$ \\
\hline $\begin{array}{l}\text { P75(Highly } \\
\text { deprived) }\end{array}$ & 31 & 25.20 & 26 & 25.24 & 31 & 25.83 \\
\hline $\begin{array}{l}\text { P25(Low } \\
\text { degree of } \\
\text { deprivation) }\end{array}$ & 22 & 17.89 & 19 & 18.45 & 32 & 26.67 \\
\hline
\end{tabular}

It reveals from Table 3 that one fourth of the individuals fall in highly deprived category, which is true for all the three groups. But low degree of deprivation is considerably higher in group 3 (26.67\%) than that of the group 1 (17.89\%) and group 2 (18.45\%).

\section{ACKNOWLEDGEMENTS}

This work is based on the project entitled, "Border Area Study: Bio-cultural diversity, Environment and Sustainable Development”, which was approved by the Anthropological Survey of India, Kolkata. The authors are grateful to the said organization. Authors are grateful to all the villagers of Kalmati and its erstwhile Chhitmahal who participated in this study.

\section{CONFLICT OF INTEREST}

The authors declare that there is no conflict of interest. 


\section{Prolonged Deprivation Profiles of three Groups: A study in a Border Village of Cooch Behar, West Bengal}

\section{REFERENCES}

Barclay, P. (1995). Income and wealth, 1.Report of the inquiry Group. York: Joseph Rowntree Foundation.

Ding, C. S. (2001). Profile analysis: Multidimensional scaling approach. Practical Assessment. Research and Evaluation, 7(16).

Drobes, D. J. et al(2001). Food deprivation and emotional reactions to food cues: Implication for eating disorders. Biological Psychology 57, 153-177.

Goodman, A., Johnson, P. and Webb, S. (1997). Inequality in the U.K. Oxford: Oxford University Press.

Gupta, R. (1994).Consequences of social and economical deprivation on academic achievement. Doctoral Dissertation .University of Calcutta.

Gupta, R. (2003). Empowerment of women and education in the context of deprivation. In: Utpal Kr. De and Bhola Nath Ghosh (Eds.), Issues on Empowerment of Women (pp.336-347). New Delhi, Mohit publication.

Harris, R. J. (1975).A Primer of Multivariate Statistics. New York, Academic press.

Havinghurst, R.J. et.al. (1962). Growing up in River City, New York, John Wiley and Sons. Inc.

Hills, J. (1995).Income and Wealth. Volume 2: A summary of the evidence. York, Joseph Rowntree Foundation.

Hill, J. (1998). Income and Wealth: The latest evidence. York, Joseph Rowntree Foundation.

Kohli, K. and Bajpai, G.S. (2006).A Comparative study of Frustration, Depression and Deprivation amongst Trainee and Serving Police Officials. Indian Journal of Criminology and Criminalistics, XXVII, No.3 Sept. - December.

Langmier,J. (1972). Personality of Deprived Children. In: Monks, F.J. (Ed) Determinants of Behavioral Development. New York, Academic Press.

Misra G. \& Tripathi, L. B. (1977).Manual for Prolonged Deprivation Scale (PDS). Agra: National Psychological Corporation.

Misra G. \&Tripathi, L. B. (1980).Psychological consequences of Prolonged Deprivation. Agra: National Psychological Corporation.

Nunnally, J. C. (1978). Psychometric Theory ( $2^{\text {nd }}$ ed.). New York, McGraw-Hill.

Nurcombe.B. (1970).Deprivation. An Essay in Definition with special consideration of Australian Aboriginals. In: G. Misra and L. B. Tripathi (Eds).Psychological Consequences of Prolonged Deprivation.

Riesman, F. (1962). The cultural Deprived Child. New York, Harper and Row.

Rencher, A.C. (1995).Methods of Multivariate Analysis. New York: John Wlley and Sons, Inc.

Tulkin, S.R. (1972). An Analysis of the Concept of Cultural Deprivation. Qtd. In: Misra and

Shreelakshmi andVankatreddy, R. (2013). Deprivation and Adjustment Among Adolescents. Indian Strams Research Journal (ISRJ), 3 (2).

Tripathi, L.B. (1980).Psychological Consequence of Prolonged Deprivations, National Psychological Corporation. Agra.

Walker, A. and Walker, C. (1987). The growing divide; A social account 1979-1987. London, CPAG Limited.

Wight, B. W., Gloniger, M. E. and Keene, P.J. (1970). Cultural deprivation: an operational definition in terms of language development. American Journal of Orthopsychiatry, 40:77-86. 